\title{
Inferring the heterogeneity, transmissivity and hydraulic conductivity of crystalline aquifers from a detailed water-table map
}

\author{
Benoît Dewandel $^{1 *}$, Julie Jeanpert ${ }^{2,3}$, Bernard Ladouche ${ }^{1}$, Jean-Lambert Join ${ }^{3}$, Jean- \\ Christophe Maréchal ${ }^{1}$ \\ 1- BRGM, D3E/NRE Unit, 1039 rue de Pinville, 34000 Montpellier, France, \\ 2- DIMENC/ Geological Survey of New Caledonia, Nouméa, New Caledonia, \\ 3- LSTUR, Université de la Réunion, BP 7151, 97715 Saint-Denis, France, \\ * corresponding author
}

\section{Abstract}

Estimating the transmissivity or hydraulic conductivity field to characterize the heterogeneity of a crystalline aquifer is particularly difficult because of the wide variations of the parameters. We developed a new approach based on the analysis of a dense network of watertable data. It is based on the concept that large-scale variations in hydraulic head may give information on large-scale aquifer parameters. The method assumes that flux into the aquifer is mainly sub-horizontal and that the water table is mostly controlled by topography, rather than recharge. It is based on an empirical statistical relationship between field data on transmissivity and the inverse slope values of a topography-reduced water-table map. This relationship is used to compute a transmissivity map that must be validated with field measurements. The proposed approach can provide a general pattern of transmissivity, or hydraulic conductivity, but cannot correctly reproduce strong variations at very local scale (less than 10 metres), and will face of some uncertainties where vertical flows cannot be neglected.

The method was tested on a peridotite (ultramafic rock) aquifer of $3.5 \mathrm{~km}^{2}$ in area located in New Caledonia. The resulting map shows transmissivity variations over about 5 orders of magnitude (average LogT: $-5.2 \pm 0.7$ ). Comparison with a map based on measured water-level data $(n=475)$ shows that the comparison between LogT-computed values and LogT data deduced from 28 hydraulic tests is estimated with an error less than $20 \%$ in $71 \%$ of cases $(\log \mathrm{T} \pm 0.4)$, and with an error less than $10 \%(\log \mathrm{T} \pm 0.2$ on average) in $39 \%$ of cases. From this map a hydraulic-conductivity map has been computed showing values ranging over 8 orders of magnitude. The repeatability of the approach was tested on a second data set of hydraulic-head measurements $(n=543)$; the mean deviation between both LogT maps is about $11 \%$. These encouraging results show that the method can give valuable parameter estimates, and can characterize aquifer heterogeneity. The computed LogT and $\operatorname{LogK}$ maps highlight the spatial distribution of parameters that show a pattern clearly controlled by the fault network of this ultramafic massif. However, the faults are mainly characterized by low-permeability zones; this differs from results on other crystalline aquifers and may be due to the fact that weathering products of peridotite are clay-like materials.

The resulting transmissivity map can be used as a starting point for modelling or to direct additional fieldwork.

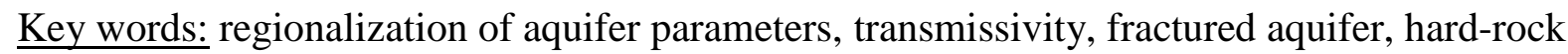
aquifer, crystalline aquifer

\section{Introduction}


Estimating the spatial variations of aquifer parameters is one of the most difficult tasks to ensure a correct calibration of hydrogeological tools and models and, therefore, a correct description of flow and transport into a groundwater system. Though it is relatively easy to evaluate these properties at a local scale, for instance hydraulic conductivity and effective porosity deduced from hydraulic tests, it is more difficult to assess their variability at aquifersystem scale, where spatial variations may occur over several orders of magnitude. This is particularly true in crystalline rocks where hydraulic conductivity can vary over 12 orders of magnitude (Tsang et al., 1996; Hsieh, 1998).

Over the past decades, various methods, combining hydrodynamic parameters, geostatistics, geological facies, inverse-modelling techniques, geophysical data, etc., have been proposed for estimating hydraulic conductivity, transmissivity or storativity at the scale of groundwater systems (e.g. Carrera et al., 2005; de Marsily et al., 2005). However, most methods were designed for alluvial and sedimentary aquifers, and require thorough field investigations.

In crystalline aquifers, the regionalization of these hydrogeological properties makes the problem much more complex because of their strong natural heterogeneity. Indeed, various degrees in fracturing and connection between fracture networks induce strong variations of properties at all scales (e.g., Paillet, 1998; Maréchal et al., 2004; Le Borgne et al., 2004, 2006). Moreover, where exposed to deep weathering, such rocks can develop several stratiform layers parallel to the weathering surface, in which hydrogeological properties are closely related to the degree of weathering (Taylor and Howard, 2000; Dewandel et al., 2006, Lachassagne et al., 2011). This increases the difficulty for regionalizing hydrodynamic parameters. Few works describe the spatial heterogeneity of aquifer parameters in crystalline aquifers, and mainly focus on transmissivity or hydraulic-conductivity mapping based on data from hydraulic tests (Razack and Lasm, 2006; Chandra et al., 2008), on classified transmissivity (i.e. indexed) maps, or on potential aquifer-zone maps (Krásný, 1993, 2000; Lachassagne et al., 2001; Darko and Krásný, 2007; Madrucci et al., 2008; Dhakate et al., 2008; Courtois et al., 2010).

More recently other approaches have been proposed, based on the concepts of stratiform layers and that large-scale variations in hydraulic head may characterize large-scale properties (Dewandel et al., 2012, 2017-in press). They base the regionalization of hydraulic conductivity on an empirical statistical relationship between the hydraulic-conductivity distribution from small-scale tests and linear-discharge rates from numerous pumped wells. For effective porosity, in the absence of recharge from rainfall, the method combines-at a cell scale - water-table fluctuation and groundwater-budget techniques, and a coarse-graining (i.e. aggregation) method. First developed for regionalizing the effective porosity for that part of the aquifer where the water table fluctuates, it has been extended in 3-D to the entire aquifer thickness while introducing the geometrical structure of the weathering profile (Dewandel et al., 2017-in press). The methods for regionalization hydraulic conductivity and effective porosity were tested on several unconfined granitic aquifers exposed to deep weathering in southern India (50 to $1000 \mathrm{~km}^{2}$ ), showing very good estimates when compared with existing data (Maréchal et al., 2004, 2006; Dewandel et al., 2006, 2010).

The present study describes a new method for estimating the spatial distribution of transmissivity and hydraulic conductivity in naturally drained crystalline aquifers. Previous methods required that aquifers were significantly influenced by pumping to cause large depressions in the water table, and/or that numerous data were available on linear-discharge rates of exploited wells (Dewandel et al., 2012, 2017-in press). The proposed approach has also advantage over other methods that use inverse modelling techniques where prescribed 
boundary flux and recharge can introduce large uncertainties on the generated hydrodynamic parameters. The present method is still based on the concept that large-scale variations in hydraulic head can provide information on large-scale hydrogeological properties. It uses detailed water-table maps, hydraulic tests and data on aquifer thickness. Its application is illustrated on a small peridotite aquifer in New Caledonia (Fig. 1a). The main objective of this study is to show that, with a few assumptions on groundwater flux and basic hydrogeological data, the method gives a reliable picture of the spatial aquifer heterogeneity as well as valid estimates of transmissivity and hydraulic conductivity. Information on deep aquifer properties of fault zones in this ultramafic environment is also given. Furthermore, we provide additional information on the functioning of aquifers in these geological environments that are still poorly understood (Boronima et al., 2003; Dewandel et al., 2004, 2005; Join et al., 2005, Nikić et al., 2013).

\section{Site description and field data}

\subsection{Location, geological history and climate}

One third of the main island of New Caledonia, Grande Terre, is underlain by a giant ophiolitic nappe (Paris, 1981), represented by a large massif in the south and several isolated massifs (klippe) on the west coast and in the northern part of the island (Fig. 1a). This Peridotite Nappe is highly fractured, resulting from its complex geodynamic history that can be summarized by: (i) Seafloor spreading of the South Loyalty Basin (SLB) during the Late Cretaceous, (ii) Paleocene-Early Eocene convergence and subsequent Eocene subduction, (iii) Obduction of the SLB over the Norfolk Ridge during the Late Eocene, (iv) Post-obduction unroofing, and finally ( $v$ ) Arrival of the New Caledonia block in Vanuatu's active eastdipping subduction zone (Dubois et al., 1974; Cluzel et al., 2001). Post-obduction extensional tectonics and uplift related to isostasic re-equilibrium during the Oligocene and Miocene took place along major listric normal faults bounding the obducted ultramafic klippes (Lagabrielle and Chauvet, 2008), isolating the massifs at various altitudes (Leguéré, 1976; Sevin et al., 2014). Since the latest Oligocene, the massifs are exposed to deep weathering (e.g. Routhier, 1953; Sevin et al., 2012) that have generated thick laterite profiles in which nickel and cobalt ores are concentrated and mined (Trescases, 1975; Llorca, 1993).

The study area is located in the north of 'Grande Terre' over a small aquifer, $3.5 \mathrm{~km}^{2}$ in area, of the Tiébaghi Massif (Fig. 1a). The massif is prospected and mined by Société Le Nickel (SLN) for nickel ore found in the saprolite layer, and in the past for chrome ore through a 3km-long tunnel within the bedrock (Moutte, 1982; Fig. 1b).

The area is characterized by an oceanic tropical climate with a hot and humid cyclonic season (December to April) followed by a cooler and drier season. Mean annual rainfall is about $1500 \mathrm{~mm}$.

\subsection{Geology of the study area}

The Tiébaghi Massif is a 20-km long and 8-km wide tectonic peridotite klippe. A lateritic profile of 20- to 70-m thick envelopes the massif and forms a gently west-dipping plateau $\left(8^{\circ}\right)$ at about $600 \mathrm{~m}$ above mean sea level (Robineau et al., 2007; Beauvais et al., 2007; Fig. 1b, Fig. 3a). Figure 2 shows a typical weathering profile of ultramafic rocks in New Caledonia (Trescases, 1975; Ouangrawa et al., 1996; Sevin, 2014). At Tiéghagi, from top to bottom, it 
consists of a thin ferruginous nodular layer and a ferricrete cap (about 5-m thick), a thin laterite (alloterite), yellow or fine saprolite (about 20-25 m), and a coarse saprolite layer (10$15 \mathrm{~m}$ ) that overlies highly weathered/fractured bedrock (Join et al., 2005; Sevin et al., 2012). Below, the bedrock is fresh (unweathered) and, from a hydraulic point of view not fractured except near faults where some fractures may conduct low water flux deeper (Join et al., 2005). This weathering profile structure is similar to that observed over granite and schist (Wyns et al., 1999; Dewandel et al., 2006; Lachassagne et al., 2011), though the fissured zone is thinner.

More than 30 electrical tomography profiles, each 1-km long, and about 600 exploration drill holes in the studied zone have revealed the structure of the weathering profile as well as a dense fault system with a dominant NW-SE - and minor N-S - direction, creating troughs and ridges (Fig. 3b; Robineau et al., 2007). The troughs correspond to graben or half-graben with a thickening of the weathering profile layers. Fig. $3 b$ shows the bedrock bottom and the fault network (only available for the northern part). On surface, the main faulted structures are outlined in the ferricrete morphology by elongate NW-SE aligned sinkholes.

\subsection{Hydrogeological setting}

Much hydrogeological work has been carried out on the massif for estimating hydrodynamic parameters, investigating groundwater flow, designing observation wells for groundwater monitoring, spring- and stream-discharge measurements, etc. (e.g. AEP, 1996; Guzik, 1996; MICA, 1999; Golder Associates, 2014). On the plateau, the static water level is at a shallow depth, typically less than $8 \mathrm{~m}$ and more or less following the topographic surface (Fig. 3c). Many seeps and springs, with flowrates of up to $5 \mathrm{~L} / \mathrm{s}$, occur along the edges of the plateau, feeding perennial waterfalls and streams on the bedrock. A conceptual model of the hydrogeological functioning of the aquifer was proposed by Join et al. (2005), highlighting that all weathered layers contribute to groundwater flow, but that each presents a particular behaviour. Ferricrete and a nodular layer form a temporary (perched) aquifer, but laterite (alloterite) and fine saprolite (isalterite) can be considered as a low-permeability layer (10${ }^{7} \mathrm{~m} / \mathrm{s}$ ) with quite high storativity because of a high clay content. The underlying coarse saprolite forms the main aquifer (about $10^{-6} \mathrm{~m} / \mathrm{s}$ ), feeding the springs and streams of the area. Deeper down where fractures extend, some groundwater flow may be deviated into bedrock, but measurements of deep flow in a 550-m long chrome-mining tunnel (Fig. 1b, not shown on maps) at 300-400 m below ground level, show that flux is very low, less than $6.5 \mathrm{~L} / \mathrm{s}$ in total.

\subsection{Water table and hydrodynamic data}

Based on the hydrogeological database of the mine, a detailed water-table map was drawn from 475 exploration wells for May 2007, resulting in a very high density water-table map (Fig. 3c). These wells are not equipped (no casing, no screen) and drilled down to the bedrock (typically they enter 3 to $10 \mathrm{~m}$ into the unfractured bedrock). Consequently, the resulting hydraulic head corresponds to an average value for the main coarse saprolite aquifer.

The map was established using standard geostatistical methods (variogram analysis and kriging). The variogram (Fig. 3d) shows that the data are spatially well-structured and that kriging results in a relevant map. A cubic model combined with a small anisotropy ratio was 
necessary to fit the experimental variogram (sill: 70, length: $1200 \mathrm{~m}$; anisotropy ratio: 1.4 , dir.: $\mathrm{N} 140^{\circ}$ ). The anisotropy direction, globally parallel to the main geological structures (Robineau et al., 2007), suggests that hydraulic-head data are at least partially controlled by the fault structure of the massif. However, the main groundwater-flow direction is S-SW, at right angles to the anisotropy direction. The mean hydraulic-head value of the map is $508.2 \mathrm{~m}$ above sea level. Additionally, another water-table database (Oct.-Nov.2006) is used to test the repeatability of the proposed method $(\S 5)$; data were analysed with the same method.

Hydrodynamic data for the coarse saprolite layer (Fig. 3c) consisted of short-duration pumping tests $\left(\mathrm{n}=11\right.$, flowrate $<1.5 \mathrm{~m}^{3} / \mathrm{h}$; duration: few tens of minutes to few hours) and one slug test (mine database), which was completed with 16 additional slug tests (this study). Pumping tests were interpreted with the standard the Theis curve fitting method (method for confined aquifer), while slug tests where interpreted with the Bouwer and Rice method (1976; method for unconfined aquifer). The literature shows that the application of analytical solutions for a confined aquifer to unconfined aquifer is possible without introducing any inaccuracy, particularly on transmissivity, when drawdowns do not exceed $25 \%$ of the aquifer thickness, which is the case in our study. All these small-scale hydraulic tests provided transmissivity data for the main aquifer near the wells. The distribution of logarithm of transmissivity, $\log \mathrm{T}$ (decimal $\log$; logarithm to base 10) has an average of -4.98 and a standard deviation of 1.11 (Fig. 4).

\section{Method for regionalizing transmissivity}

The proposed method for evaluating the transmissivity field is based on the concept that large-scale variations in hydraulic head may give information on large-scale properties.

Where the aquifer is naturally drained (no groundwater abstraction), where vertical flow can be neglected, and where the water table is in pseudo-steady state and mainly controlled by topography rather than recharge (Haitjema and Mitchell-Bruker, 2005), it can be assumed that the gradient of the water-table map depends on both topographic slope and aquifer horizontal transmissivity (Fig. 5a, c). Otherwise, recharge will control the water table (Fig. 5b), leading to a gradient depending on aquifer horizontal transmissivity and not topography.

For a water table controlled by topography, as is expected for medium- to low-permeable aquifers, a flat topography, and where groundwater flow is horizontal, the continuity equation (Darcy's law) for unit aquifer width is:

$Q=T_{1} \operatorname{gradh}_{1}=T_{2} \operatorname{gradh}_{2}=\ldots .=T_{n} \operatorname{gradh}_{n}$

Where $Q$ : is the horizontal flux $\left(\mathrm{m}^{3} / \mathrm{s} / \mathrm{m}\right), T i=$ aquifer horizontal transmissivity $\left(\mathrm{m}^{2} / \mathrm{s}\right), \operatorname{grad} h_{i}$ : hydraulic gradient (dimensionless). Because of the flat topography, the use of Eq.1 along the same flow line will give high transmissivity values where the hydraulic gradient is low and low values where the gradient is high. However, as shown on Figure 5c, the hydraulic gradient is also strongly influenced by topography. Therefore, where the topographic level is almost stable (left part of Fig. 5c) the variation in hydraulic gradient depends more on variations in aquifer transmissivity, in fact inversely related to the hydraulic gradient, whereas in the right part of Fig. 5c it is more controlled by topographic slope because of stronger variation in elevation. 
To obtain information on transmissivity where the water table is related to topography, the problem is thus to eliminate the influence of elevation on water-table data. To verify if the water table is expected to be largely controlled by topography, the criterion proposed by Haitjema and Mitchell-Bruker (2005)—based on a Dupuit-Forchheimer model solving the problems shown on Figures $5 \mathrm{a}$ and $\mathrm{b}$ - can be used as a bench mark:

$$
C_{H M B}=\frac{R L^{2}}{8 T d}
$$

where $\mathrm{R}(\mathrm{m} / \mathrm{s})$ is the average annual recharge rate, $\mathrm{L}(\mathrm{m})$ the average distance between surface waters, $\mathrm{T}\left(\mathrm{m}^{2} / \mathrm{s}\right)$ the horizontal aquifer transmissivity, and $\mathrm{d}(\mathrm{m})$ the maximum distance between the average surface-water levels and terrain elevation. They stated that if $C_{H M B}>1$, the water table is largely controlled by topography (Fig. 5a); otherwise it is controlled by recharge (Fig. 5b).

However, most parameters of Eq. 2 could not be defined precisely and we thus assumed the following ranges for our study area: $100<\mathrm{R}<400 \mathrm{~mm} / \mathrm{y}, 500<\mathrm{L}<1000 \mathrm{~m}$ (corresponding to the minimum spacing between two streams up to the plateau width; Fig. $3 \mathrm{a}$ ), $\mathrm{T}=10^{-5} \mathrm{~m}^{2} / \mathrm{s}$ (average of hydraulic tests data, Fig. 4) and $5<\mathrm{d}<10 \mathrm{~m}$. We found that $C_{H M B}$ ranges between 1 and 40 , and concluded that the water table is essentially controlled by topography.

Figure 6 shows the relationship between hydraulic-head data and elevation for each of the 475 wells, and thus the effect of elevation on well-head data. This very good relationship $\left(\mathrm{R}^{2}=0.99\right)$ is also consistent with the evaluated Haitjema and Mitchell-Bruker's criterion $\left(C_{H M B}\right)$. Therefore, subtracting this trend from the original water-level data will remove the overall effect of topography and results in flattening the hydraulic-head data, thus only leaving those variations that are controlled by transmissivity. A reduced water-table map now can be drawn (Fig. 7) from which a slope map is computed. It is expected that the low values represent the highest transmissivity zones, whereas the high values show the lowtransmissivity zones. Finally, the statistical distribution of the slope data-in practice the Log of the inverse of the slope - is compared to that of the transmissivity data. Once a relationship between the two distributions is found, a transmissivity map can be computed from inverseslope data that has to be validated by the local estimates, the ones that served to establish the statistical distribution of LogT (Fig. 4).

\section{4- Results}

The studied aquifer, with only minor vertical groundwater flow compared to horizontal flow, conforms to the initially established hypotheses and allows testing the proposed methodology.

The variogram of reduced hydraulic-head data (Fig. 7a) shows that the data are spatially wellstructured and that kriging results in a relevant map (Fig. 7b). An exponential model combined with a small anisotropy ratio was also necessary to fit the experimental variogram (sill: 5.1, length: $190 \mathrm{~m}$; anisotropy ratio: 1.8 , dir.: $\mathrm{N} 140^{\circ}$ ). The anisotropy direction is still globally parallel to the main geological structures, again suggesting a relationship of this parameter with the geological structure of the massif. The reduced-water-table map has been computed on a grid of $20 \times 20 \mathrm{~m}$ cells (Fig. $7 \mathrm{~b}$ ), with values ranging from -3.3 to $5.3 \mathrm{~m}$ with an average of $0.57 \mathrm{~m}$ and a standard deviation of $1.67 \mathrm{~m}$. From this map, a slope map was derived (Fig. 7c), showing an alignment of structures approximately in the main NW-SE structural direction of the massif. Values vary over three orders of magnitude between 0.01 
and $3(\mathrm{~m} / \mathrm{m})$, with an average and standard deviation of $0.34 \pm 0.38(\mathrm{~m} / \mathrm{m})$. The inverse of the slope was computed and shows a near log-normal distribution with an average logarithm of 1/slope, $\log (1 /$ slope), of -0.33 and a standard deviation of 0.31 (Fig. $7 d$ ).

Applying the method described above, the resulting empirical relationship between both distributions of 1/slope and transmissivity shows a successful match between modelled and observed distributions, with a linear regression coefficient (square form), $\mathrm{R}^{2}$, of 0.91 (Fig. 8). The relation is:

$$
\mathrm{T}=1.1 \times 10^{-5}(1 / \text { slope })-1.6 \times 10^{-5}
$$

Eq. 3 indicates a linear relationship that partially verifies Darcy's Law in its leftproportionality - part. However, there is a negative constant that suggests that the slope map does not exactly reflect the aquifer transmissivity everywhere. The negative value corresponds to the highest slope values $(>0.7)$ and probably was introduced by a bias because of the average relationship used for removing the impact of topography on hydraulic-head data. Even if the use of this relationship is appropriate at the aquifer scale, this is probably not true for some small perimeters of the area where the trend defined on Fig. 6 may locally differ. These high-slope areas, correspond to the darkest zones of Fig. 7c, and cover about $30 \%$ of the data. Nonetheless, such zones may correspond to low-transmissivity values, but with an exaggerated slope. Further explanations for this negative constant are also given in the discussion section.

The computed-transmissivity map (on a logarithmic scale and a grid with 20x20 m cells; Fig. 9a) is based on a geostatistical approach that uses Eq. 3 for slope values less than 0.7 $(\mathrm{n}=5851)$. The variogram of the computed LogT (Fig. 9b) shows that the data are spatially structured. An exponential model with an anisotropy ratio has been used to fit the experimental variogram (sill: 0.24 , length: $115 \mathrm{~m}$; anisotropy ratio: 1.4 , dir.: $\mathrm{N} 140^{\circ}$ ). The average and standard deviation of the computed-LogT are $-5.2 \pm 0.7$.

In order to verify if the produced map conforms to field data, local LogT-computed values from the map were compared to LogT data deduced from the 28 hydraulic tests (Fig. 9c). Note that no local transmissivity values from hydraulic tests were used for drawing the map. The comparison shows that in $71 \%$ of cases, the computed LogT is estimated with an error less than $20 \%$, which corresponds to $\log \mathrm{T} \pm 0.4$ on average. And in $39 \%$ of cases, the computed $\log \mathrm{T}$ is estimated with an error less than $10 \%$, here corresponding to $\log \mathrm{T} \pm 0.2$ on average. Therefore, the method produces reasonable estimates of transmissivity considering the strong heterogeneity of this fractured system with transmissivity variations of almost 5 orders of magnitude. In some cases, however- $29 \%$ of the dataset corresponding to $60 \%$ of the dataset with $\operatorname{LogT}>-4.5-$, high-transmissivity areas are not correctly estimated by the map. This is due to the intrinsic characteristic of fractured systems, where high- and lowpermeability zones coexist at a local scale. Therefore, these values are probably very local and not representative of average aquifer properties at the scale of some tens of metres. This point was already mentioned by Dewandel et al. (2012).

The hydraulic-conductivity map, on a logarithmic scale (LogK; grid with 20x20 m cells) (Fig. 9d), was based on the transmissivity map and on the thickness of the saturated aquifer deduced from Fig. 3b, c. The LogK variogram (Fig. 9e) is similar to that of LogT and shows a strong spatial dependency. The average and standard deviation of the computed LogK are $6.7 \pm 0.8$, and values range over 8 orders of magnitude. Hydraulic-conductivity values are consistent with the ones mentioned by Join et al. (2005), but also with those of the fissured zone of Oman peridotite (Dewandel et al., 2004, 2005). 


\section{Repeatability and validation of the method}

To verify if the method is repeatable and to validate it, we tested it on a second set of hydraulic-head data. This new data set provides more water-table data $(n=543)$, but they are less precise because they were measured over a period of two months, between October and November 2006, which may have introduced discrepancies because of potential small recharge events during the measuring period. The mean hydraulic-head value for this map is 507.0 metres above sea level, a value slightly lower than the one established in May 2007 (508.2 m.a.s.1.). A new relationship of elevation $v$ s. hydraulic head $\left(\mathrm{y}=0.9837 \mathrm{x}+1.5371 ; \mathrm{R}^{2}\right.$ $=0.99$ ) and a new Eq. $3\left[\mathrm{~T}=1.4 \times 10^{-5}\right.$ (1/slope) $\left.-0.9 \times 10^{-5 ;} \mathrm{R}^{2}: 0.88\right]$, etc., were established from this data set to compute a new LogT map (Fig. 10a). This map shows a similar pattern to the one established with May 2007 data (Fig. 9a). The data are still spatially structured (Fig. 10b), with a variogram model close to the previous one (model: exponential, sill: 0.32 , length: $85 \mathrm{~m}$; anisotropy ratio: 1.4 , dir.: $\mathrm{N} 140^{\circ}$ ). The average and standard deviation of the computed LogT for 2006 is close to the earlier one, $-5.2 \pm 0.7$.

The mean deviation between both LogT-2006 and LogT-2007 maps has been computed and Figure 11a presents the results. The average mean deviation is about $11 \%$ with a standard deviation of $9 \%$ (Fig. 11b), and without dependency according to LogT ranges (random distribution of the deviation; Fig. 11c). Note that the highest deviation is obtained in the south-south-eastern part of the area where information on water level data is available for the Oct.-Nov. 2006 data set only (Figs. 3c and 10a). These results confirm the May 2007 map, and thus the proposed approach.

\section{6- Discussion}

We present an innovative method for estimating the spatial distribution of aquifer transmissivity and hydraulic conductivity in crystalline aquifers. The approach builds upon the author's earlier work (Dewandel et al., 2012) and considers here the case where there is no pumped well in the area, but sufficient well-head data exist to produce a detailed water-table map. The method's assumptions only consider that flux into the aquifer is mainly subhorizontal and that the water-table is mostly controlled by topography. Where the water table is recharge controlled (not the case here), the water-table map gradient can directly be used for estimating the transmissivity field. Our approach has a significant advantage over other methods, for instance those that use inverse modelling techniques where boundary flux and recharge can introduce large uncertainties on the generated hydrodynamic parameters. In heterogeneous media, like in the studied case, such hydrological conditions are often unknown and particularly difficult to assess.

The relationship between the distributions of inverse-slope (1/slope) and field-transmissivity data does not fully satisfy Darcy's Law because of the constant in Eq. 3 (if it fully satisfies this law, the constant should have been nil). The negative constant is believed to be introduced by the aquifer-scale relationship used for removing the effect of topography on hydraulic-head data, which may differ on a local scale. Another reason that may also explain this bias is our basic assumption that vertical groundwater flux can be neglected compared to the horizontal one. Though this hypothesis, at aquifer scale, is plausible because of minor deep-groundwater flux as confirmed by measurements within the chrome-mining tunnel $(<71 / s)$, it is possible that locally_within, or near, vertical faults — vertical flux cannot be 
neglected. Consequently, some high slope values on Fig. 7c may reflect such flux that the proposed method erroneously assimilates to low horizontal-transmissivity zones. In these cases, there is probably a vertical transmissivity component that the method cannot evaluate. The method also assumes that the water table is topography-controlled, which is the case at aquifer scale, but locally it may be recharge controlled, thus introducing an additional bias.

To test the validity of our approach, we first verified that the produced LogT map conforms to field data, which gave encouraging results (Fig. 9c). Then, to verify if the method is repeatable, we tested it on a second set of hydraulic-head data (Fig.10a) that confirms the previously established LogT map (Figs.11) and thus the proposed approach.

The computed LogT and LogK maps (Fig. 9a, d; Fig. 10a) show a strong spatial dependency with zones of equivalent properties elongated in a roughly $\mathrm{N} 140^{\circ}$ direction. This direction corresponds to the main fault directions of the Tiébaghi Massif (Robineau et al., 2007), which shows that fault presence strongly influences the hydrodynamic properties, and thus groundwater flux in the rock. Low-permeability zones $(\operatorname{LogK}<-7)$ are quasi-systematically associated with the main fractures. This is explained by the fact that the weathering of peridotite produces mostly low-permeable (clay-bearing, i.e. alloterite) materials that mostly act as barrier to groundwater flow. This behaviour is very different to what can be observed in granite and gneiss aquifers, where deepening of the weathering front along faults, contact zones, veins, etc., generally enhances hydrodynamic aquifer properties (Dewandel et al., 2011; Lachassagne et al., 2011). However, deeper in the bedrock some of these faults are still slightly productive as shown by the flux measurements in the chrome-mining tunnel at 300 to $400 \mathrm{~m}$ depth.

An original feature of the peridotite aquifer in New Caledonia is the presence of subsurface pseudo-karst structures (e.g., Genna et al., 2005) that are unknown from other studied peridotite aquifers, probably because the weathering profile, there, is less developed (Cyprus: Boronima et al., 2003; Oman: Dewandel et al., 2005; Serbia: Nikić et al., 2013). In the Tiébaghi Massif, sinkholes affect the morphology of the ferricrete surface. Aligned and elongated along the main NW-SE fault system, they mainly develop above horst border faults (Fig. 1b), which may reflect underground flow paths that can evacuate the finest weathering products (Genna et al., 2005). However, such sinkholes are now considered as poorly active to inactive because they are commonly filled with water and characterized by low-water level decline. One reason that may explain why the Tiébaghi sinkholes are almost inactive is the almost right angle between the main fault directions (NW-SE and minor N-S) and the SSWdirected groundwater flux, which does not favour the underground evacuation of (finegrained) weathering products and thus the functioning of these structures. This is not the case in southern New Caledonia, where a large number of sinkholes affects the ferricrete surface (around 60 sinkholes $/ \mathrm{km}^{2}$ ), and where some of the largest are active (Jeanpert et al., 2016). They are elongated and distributed over 50-m-wide zones oriented $\mathrm{N} 140^{\circ}$ inherited from tectonic fracturing. However, the role of groundwater-flux directions and main fault directions to explain the development of sinkholes and/or their functioning needs to be confirmed by further works.

\section{Conclusions}


We show that basic analyses of spatially detailed information on hydraulic-head data can be used for characterizing the heterogeneity of an aquifer and evaluating its transmissivity or hydraulic conductivity fields. This is very useful in fractured media where in-situ measurements of hydrodynamic parameters are generally not sufficiently dense to allow a relevant mapping. The method requires detailed information on the spatial variations of hydraulic head in the aquifer and on the statistical distribution of aquifer transmissivity, and the establishment of an empirical statistical relationship between field data on transmissivity and the inverse slope values of a topography-reduced water-table map. Here, hydrodynamic parameters on 28 locations and a density of up to 155 water level observations per $\mathrm{km}^{2}$ were used to evaluate the transmissivity field of an aquifer from which transmissivity varies on about 5 orders of magnitude. We assume that the water table is mainly controlled by topography (generally the case for medium- to low-permeable aquifers) and that groundwater flux is mostly sub-horizontal. Consequently, where vertical flux is significant, transmissivity or hydraulic conductivity would be under-estimated.

Its application to the peridotite Tiébaghi Massif (New Caledonia) has given very encouraging results with only $11 \%$ deviation between two LogT maps computed with different hydraulichead data sets (Oct.-Nov. 2006 and May 2007). In addition, there is quite good consistency between measured and computed $\log \mathrm{T}$ as, in $71 \%$ of cases, the computed-LogT is estimated with an error of $<20 \%$. The proposed approach will thus give the general pattern of transmissivity or hydraulic conductivity, but cannot correctly reproduce strong variations at very local scale $(<10 \mathrm{~m})$. Maps highlight the spatial distribution of the hydrodynamic parameters and show a pattern clearly controlled by the fault network of the massif. However, compared to other crystalline aquifers, the intense weathering along faults seems to seal the structures.

The method can be very useful for siting bore wells (e.g. for water supply), but also for identifying potential draining zones. For mining, it may provide valuable information for mine design, such as managing the risk of groundwater inflow, designing the pumping capacity for open pits, or safeguarding ore-storage and tailings areas.

In terms of numerical modelling, the resulting hydrodynamic parameters, even if given with a certain amount of uncertainty, can help in identifying the general pattern of parameters, thus providing valuable information on aquifer heterogeneity.

Further works should test the robustness of the evaluated parameters with a numerical approach, applying the method to other aquifers including the ones where the water table is mainly recharge controlled, and adapting it to larger aquifers with scarcer data sets. Another important issue would be to define the optimal number of measurements required (hydraulic head, and hydraulic tests) to use this method. A priori, it should depend on the heterogeneity of the aquifer, highly heterogeneous aquifers, as the one presented here, requiring a very dense observation network. Geostatistical tools are foreseen to achieve this issue.

\section{Acknowledgements}

The authors are grateful to the research-sponsorship from CNRT (New Caledonia) and BRGM (France) under the CNRT programme "HYPERK: Hydrogeology of mined massifs". We are also grateful to Société Le Nickel for access to the hydrogeological database of the Tiébaghi Massif. The three anonymous Journal referees are thanked for their useful remarks 
and comments that improved the quality of the paper. We thank Dr. H.M. Kluijver for revising the English text.

\section{References}

A2EP, 1996. Étude de l'hydrogéologie du massif de Tiébaghi, A2EP, NCH 96/09 02, 1996, $26 \mathrm{p}$.

Beauvais, A., Parisot, J.C., Savin, C., 2007. Ultramafic rock weathering and slope erosion processes in a South West Pacific tropical environment. Geomorphology, 83, 1-13.

Boronina A, Renard P, Balderer W, Christodoulides A, 2003. Groundwater resources in the Kouris catchment (Cyprus): data analysis and numerical modelling. J. Hydrol., 271, 130-149.

Bouwer H., Rice R.C., 1976. A slug test for determining hydraulic conductivity of unconfined aquifers with completely or partially penetrating wells, Water Resour. Res., 12 (3), 423-428.

Carrera J., Alcolea A., Medina A., Hidalgo J., Slooten L.J., 2005. Inverse problem in hydrogeology. Hydrogeol J., 13, 206-222.

Chandra, S., Ahmed, S., Ram, A., Dewandel, B., 2008. Estimation of hard rock aquifers hydraulic conductivity from geoelectrical measurements: A theoretical development with field application. J. of Hydrology, 357, 218- 227.

Cluzel D., Aitchison J.C., Picard C. 2001. Tectonic accretion and underplating of mafic terranes in the Late Eocene intraoceanic fore-arc of New Caledonia (Southwest Pacific): geodynamic implications. Tectonophysics, 340, no. 1/2: 23-59.

Courtois, N., Lachassagne, P., Wyns, R., Blanchin, R., Bougaïré, F.D., Somé, S., Tapsoba, A., 2010. Large-scale mapping of hard-rock aquifer properties applied to Burkina Faso, Ground Water, 48, (2), 269-283.

Darko, Ph.K., Krásný, J., 2007. Regional transmissivity distribution and groundwater potential in hard rock of Ghana. In: Krásný J. \& Sharp J.M. (eds.): Groundwater in fractured rocks, IAH Selected Papers, 9, 1-30. Taylor and Francis.

de Marsily G., Delay F., Gonçalvès J., Renard Ph., Teles V., Violette S., 2005. Dealing with spatial heterogeneity. Hydrogeology J. 13, 161-183.

Dewandel B., Lachassagne P., Qatan A., 2004. Spatial measurements of stream baseflow, a relevant method for aquifer characterization and permeability evaluation. Application to a hard rock aquifer, the Oman ophiolite, Hydrol. Processes 18, 3391-3400.

Dewandel B., Lachassagne P., Boudier F., Al-Hattali S., Ladouche B., Pinault J.L., AlSuleimani Z., 2005. A conceptual hydrogeological model of ophiolite hard-rock aquifers in Oman based on a multiscale and a multidisciplinary approach. Hydrogeol. J., 13, (5-6), 708726.

Dewandel, B., Lachassagne, P., Wyns, R., Maréchal, J.C., Krishnamurthy, N.S., 2006. A generalized hydrogeological conceptual model of granite aquifers controlled by single or multiphase weathering. J. of Hydrology, 330, 260-284, doi:10.1016/j.jhydrol.2006.03.026. 
Dewandel, B., Perrin, J., Ahmed, S., Aulong, S., Hrkal, Z., Lachassagne, P., Samad, M., Massuel S., 2010. Development of a tool for managing groundwater resources in semi-arid hard rock regions. Application to a rural watershed in south India. Hydrological Processes, 24, 2784-2797.

Dewandel, B., Lachassagne, P., Zaidi, F.K., Chandra, S., 2011. A conceptual hydrodynamic model of a geological discontinuity in hard rock aquifers: example of a quartz reef in granitic terrain in South India. J. of Hydrology, 405, 474-487.

Dewandel, B., Maréchal, J.C., Bour, O., Ladouche, B., Ahmed, S., Chandra, S., Pauwels, H., 2012. Upscaling and regionalizing hydraulic conductivity and effective porosity at watershed scale in deeply weathered crystalline aquifers. J. of Hydrology, 416-417, 83-97. doi:10.1016/j.jhydrol.2011.11.038.

Dewandel, B., Caballero, Y., Perrin, J., Boisson, A., Dazin, F., Ferrant, S., Chandra, S., Maréchal, J.C., 2017, in press. A methodology for regionalizing 3-D effective porosity at watershed scale in crystalline aquifers. Submitted to Hydrological Processes.

Dhakate, R., Singh, V.S., Negi, B.C., Chandra, S., Ananda Rao V., 2008. Geomorphological and geophysical approach for locating favourable groundwater zones in granitic terrain, Andhra radish, India. J. of Env. Management, 88, 1373-1383.

Dubois J., Launay J., Recy J., 1974. Uplift movements in New Caledonia-Loyalty Islands area and their plate tectonics interpretation. Tectonophysics, 24, no. 1: 133-150.

Genna, A, Maurizot, P., Lafoy, Y., Augé, T., 2005. Contrôle karstique de minéralisations nickélifères de Nouvelle-Calédonie. C. R. Geoscience, 337, 367-374.

Golder Associates. 2014. Impact of the Tiébaghi mine on the groundwater resource, in French. Effets du développement de la mine de Tiébaghi sur la ressource en eau souterraine SLN. Rapport Golder Ass.

Guzik, J.M., 1996. Premiers résultats des relevés effectués sur les nouvelles installations de Tiébaghi, S.L.N., 17 p.

Haitjema, H.M., Mitchell-Bruker, S., 2005. Are water tables a subdued replica of the topography? Ground Water, 43, 781-786. doi: 10.1111/j.1745-6584.2005.00090.x

Hsieh,, P.A., 1998. Scale effects in fluid flow through fractured geological media, in Scale Dependence and Scale Invariance in Hydrology, ed. G. Sposito, 335-353, Cambridge Univ. Press, Cambridge, U. K.

Jeanpert, J., Genthon, P., Maurizot, P., Folio, J.L., Vendé-Leclerc, M., Serino, J., Join, J.L., Iseppi, M., 2016. Morphology and distribution of dolines on ultramafic rocks from airborne LIDAR data: the case of southern Grande Terre in New Caledonia (SW Pacific). Earth Surface Processes and Landforms.

Join, J.L., Robineau, B., Ambrosi, J.P., Costis, C., Colin, F., 2005. Groundwater in ultramafic mined massifs of New Caledonia. C. R. Geoscience, 337, 1500-1508

Krásný, J., 2000. Geologic factors influencing spatial distribution of hard rock transmissivity. In: Sililo O et al (eds): Groundwater: Past Achievements and Future Challenges. Proc. 30 IAH Congress, 2000, 187-191, Cape Town, Balkema, Rotterdam. 
Krásný, J., Sharp, J.M., 2007. Hydrogeology of fractured rocks from particular fractures to regional approaches: state-of-the-art and future challenge. In: Krásný J. \& Sharp J.M. (eds.): Groundwater in fractured rocks, IAH Selected Papers, 9, 1-30. Taylor and Francis.

Lachassagne, P., Wyns, R., Bérard, P., Bruel, T., Chéry, L., Coutand, T., Desprats, J.F., Le Strat, P., 2001. Exploitation of high-yield in hard-rock aquifers: Downscaling methodology combining GIS and multicriteria analysis to delineate field prospecting zones. Ground Water, $39,568-581$.

Lachassagne, P. Wyns, R., Dewandel, B., 2011. The fracture permeability of hard rock aquifers is due neither to tectonics, nor to unloading, but to weathering processes. Terra Nova, 23, No. 3, 145-161. doi: 10.1111/j.1365-3121.2011.00998.x

Lagabrielle, Y., Chauvet, A. 2008. The role of extensional tectonics in shaping Cenozoic New-Caledonia. Bull. Soc. Géol. France, 179, 315-329.

Le Borgne T., Bour O., de Dreuzy J.R., Davy P. and Touchard F., 2004. Equivalent mean flow models for fractured aquifers: insights from a pumping tests scaling interpretation. Water Resour. Res., 40, W03512, 1-12.

Le Borgne, T., Bour, O., Paillet, F.L, Caudal, J.P., 2006. Assessment of preferential flow path connectivity and hydraulic properties at single-borehole and cross-borehole scales in fractured aquifer. J. Hydrology, 328, 347-359.

Leguéré, L., 1976. Des corrélations entre la tectonique cassante et l'altération supergène des péridotites de Nouvelle-Calédonie, Doctoral thesis, Université des sciences et techniques du Languedoc, 1976, $80 \mathrm{p}$.

Llorca, L., 1993. Metallogeny of supergene cobalt mineralization, New Caledonia, Aust. J. Earth Sci. 40, 377-385.

Madrucci, V., Taioli, F., de Araujo C.C., 2008. Groundwater favourability map using GIS multicriteria data analysis on crystalline terrain, Sao Paulo State, Brazil. J. of Hydrology, 357, 153-173.

Maréchal, J.C., Dewandel, B., and Subrahmanyam, K., 2004. Contribution of hydraulic tests at different scales to characterize fracture network properties in the weathered-fissured layer of a hard rock aquifer. Water Resourc. Res.,40, W11508.

Maréchal, J.C., Dewandel, B., Ahmed, S., Galeazzi, L., 2006. Combining the groundwater budget and water table fluctuation methods to estimate specific yield and natural recharge. J. of Hydrology, 329, 1-2, 281-293, doi:10.1016/j.jhydrol.2006.02.022.

MICA, 2009. Société Le Nickel - SLN, centre minier de Tiébaghi, site Dôme (Province Nord). Etat initial, étude hydrogéologique, Avril 2009, n08-022, MICA Environnement NC.

Moutte, J., 1982. Chromite deposits of the Tiébaghi ultramafic massif, New Caledonia, Econ. Geol. 77, 576-591.

Nikić, Z., Srećković-Batoćanin, D., Burazer, M., Ristić, R., Papić, P., Nikolić, V., 2103. A conceptual model of mildly alkaline water discharging from the Zlatibor ultramafic massif, western Serbia. Hydrogeol. J. 21, 1147-1163. 
Ouangrawa, M., Trescases, J.J., Ambrosi, J.P., 1996. Évolution des oxydes de fer au cours de l'altération supergène de roches ultrabasiques de Nouvelle-Calédonie, C. R. Acad. Sci. Paris, Ser. Ia 323, 243-249.

Paillet, F.L., 1998. Flow modelling and permeability estimations using borehole flow logs in heterogeneous fractured formation. Water Resour. Res., 34 (5), 997-1010.

Paris, J.P., 1981. Géologie de la Nouvelle-Calédonie : un essai de synthèse, BRGM, 278 p.

Razack, M., Lasm, T., 2006. Geostatistical estimation of the transmissivity in a highly fractured metamorphic and crystalline aquifer (Man-Danane Region, Western Ivory Coast). J. of Hydrology, 325, 164-178.

Robineau, B., Join, J.L., Beauvais, A., Parisot, J.C., Savin, C., 2007. Geoelectrical imaging of a thick regolith developed on ultramafic rocks: groundwater influence. Aust. J. Earth Sci., 54, 773-781.

Routhier, P, 1953. Étude géologique du versant occidental de la Nouvelle-Calédonie entre le col de Boghen et la pointe d'Arama, Mém. Soc. Géol. France, Nouvelle Série 32 (67) 1-127.

Sevin, B., Ricordel-Prognon, C., Quesnel, F., Cluzel, D., Lesimple, S., Maurizot, P., 2012. First palaeomagnetic dating of ferricrete in New Caledonia: new insight on the morphogenesis and palaeoweathering of 'Grande Terre'. Terra Nova, 24, 77-85.

Sevin, B. 2014. Mapping the regolith on ultrabasic rocks in New Caledonia: location in space and time of nickel ore, in French. Cartographie du régolithe sur formation ultrabasique de Nouvelle-Calédonie : localisation dans l'espace et le temps des gisements nickélifères., $\mathrm{PhD}$ Thesis, Université de Nouvelle-Calédonie.

Taylor, R., Howard, K., 2000. A tectono-geomorphic model of the hydrogeology of deeply weathered crystalline rock: evidence from Uganda. Hydrogeol. J., 8, 279-294.

Trescases, J.J., 1975. L'évolution géochimique supergène des roches ultrabasiques en zone tropicale : formation des gisements nickélifères de Nouvelle-Calédonie, Mém. Orstom, 78, , $259 \mathrm{p}$.

Tsang Y.W., Tsang C.F., Hale F.V., Dverstorp B., 1996. Tracer transport in a stochastic continuum model of fractured media, Water Resour. Res., 32 (10), 3077-3092, doi:10.1029/96WR01397.

Wyns, R., Gourry, J.C., Baltassat, J.M., Lebert, F., 1999. Caractérisation multiparamètres des horizons de subsurface (0-100 m) en contexte de socle altéré. In: 2ème Colloque GEOFCAN, ed. I. BRGM, IRD, UPMC, 105-110, Orléans, France.

Wyns, R., Baltassat, J.M., Lachassagne, P., Legchenko, A., Vairon, J., Mathieu, F., 2004. Application of SNMR soundings for groundwater reserves mapping in weathered basement rocks (Brittany, France), Bull. Soc. Géol. France, 175, (1), 21-34. 


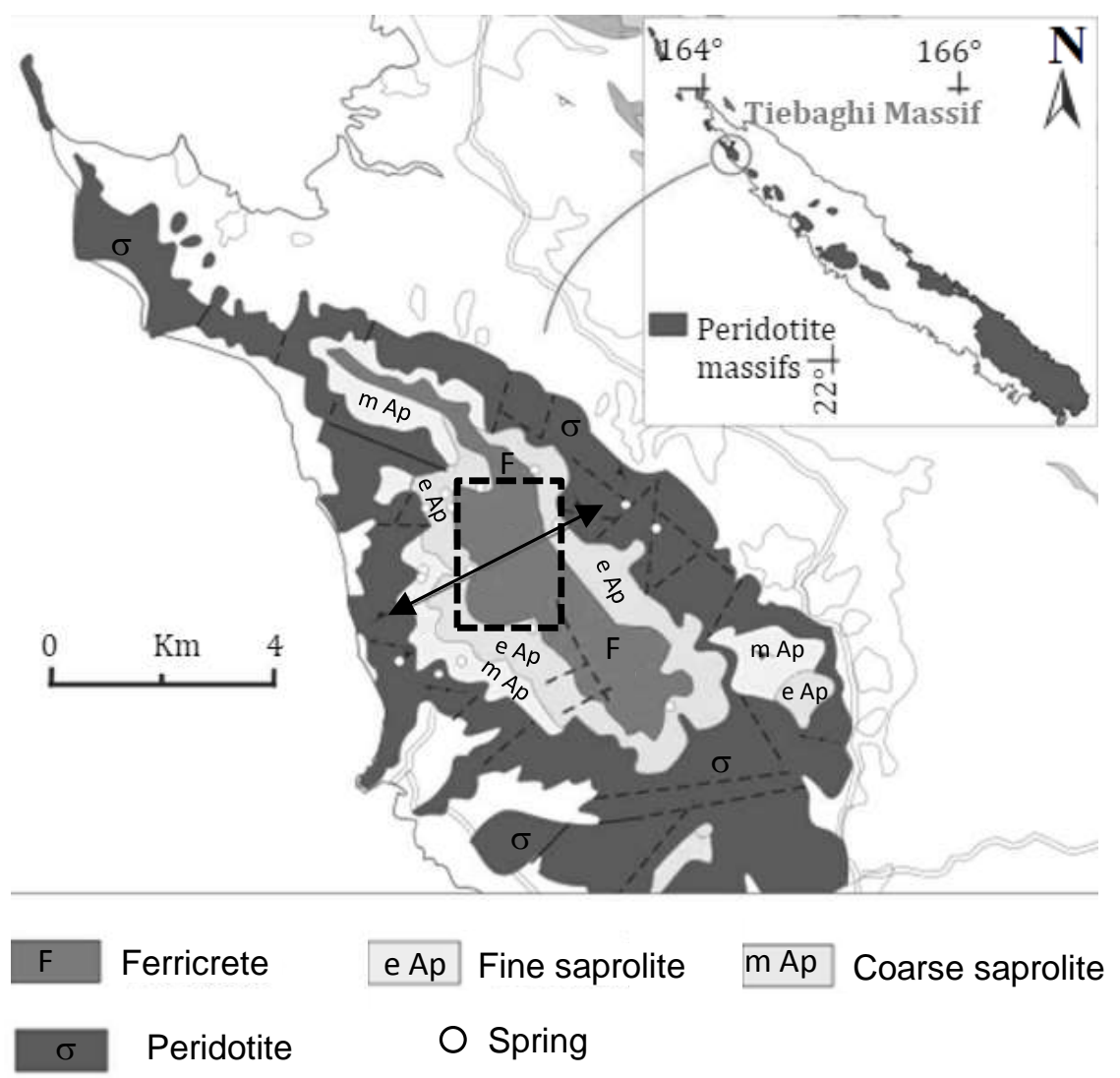

a)

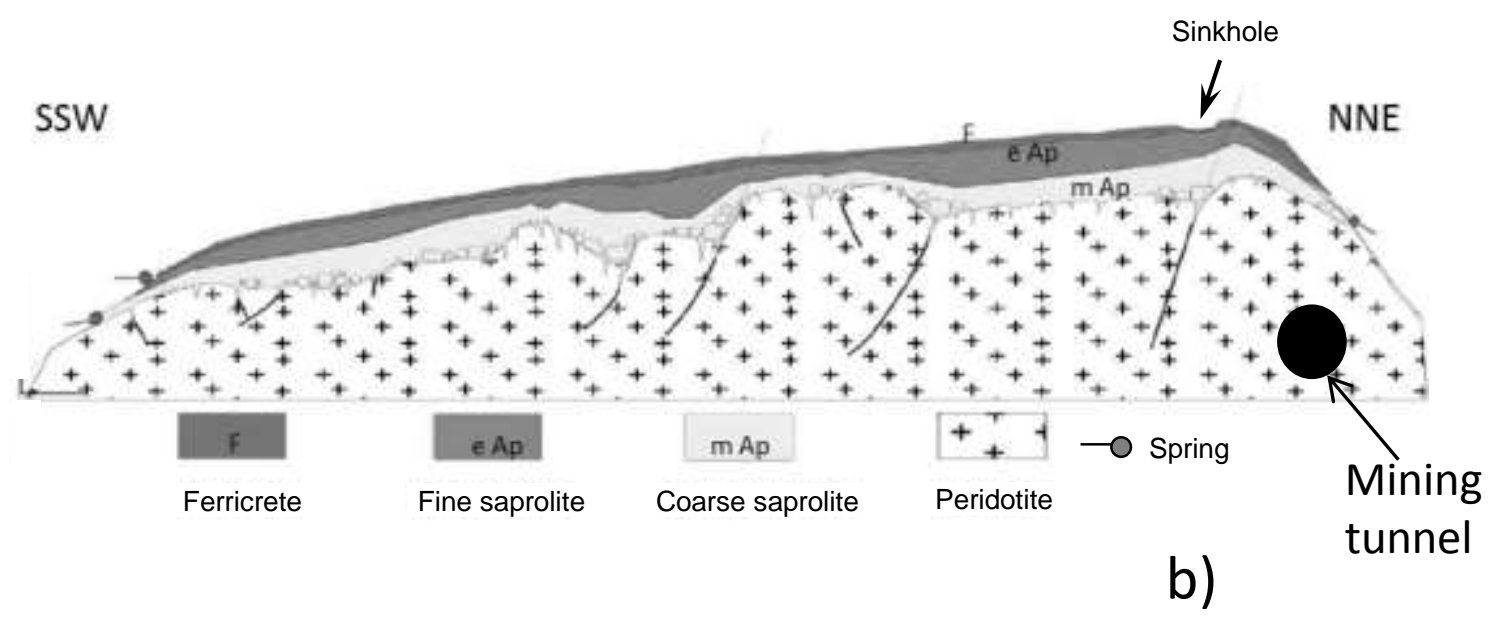

Figure 1 a) Simplified geological map of the study area $\left(3.5 \mathrm{~km}^{2}\right.$, Tiébaghi Massif, New 601 Caledonia). b) Geological cross section (arrow on Fig. 1a) showing the stratiform structure of the weathering profile (modified from Join et al., 2005) and approximate location of the chrome-mining tunnel. 


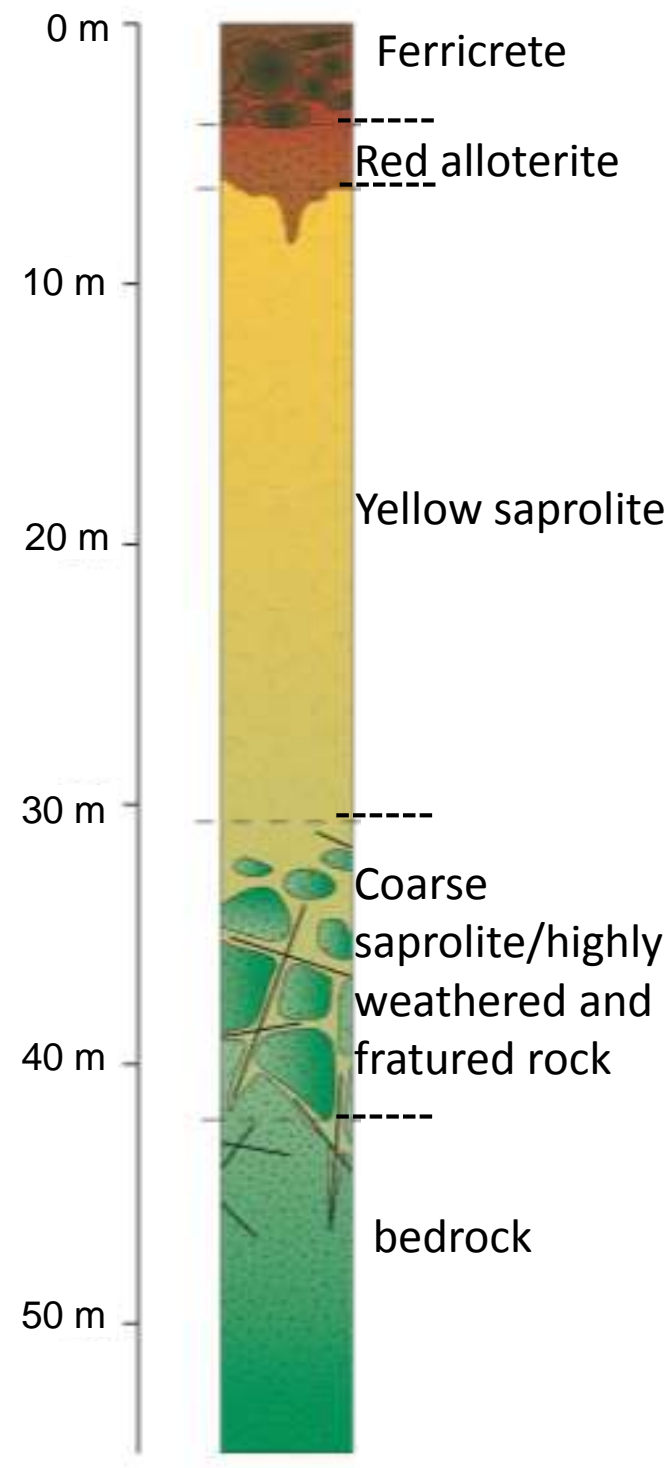

605 Figure 2 Typical weathering profile of ultramafic rocks in New Caledonia (Trescases, 1975; 606 Ouangrawa et al., 1996; Sevin et al., 2012). 

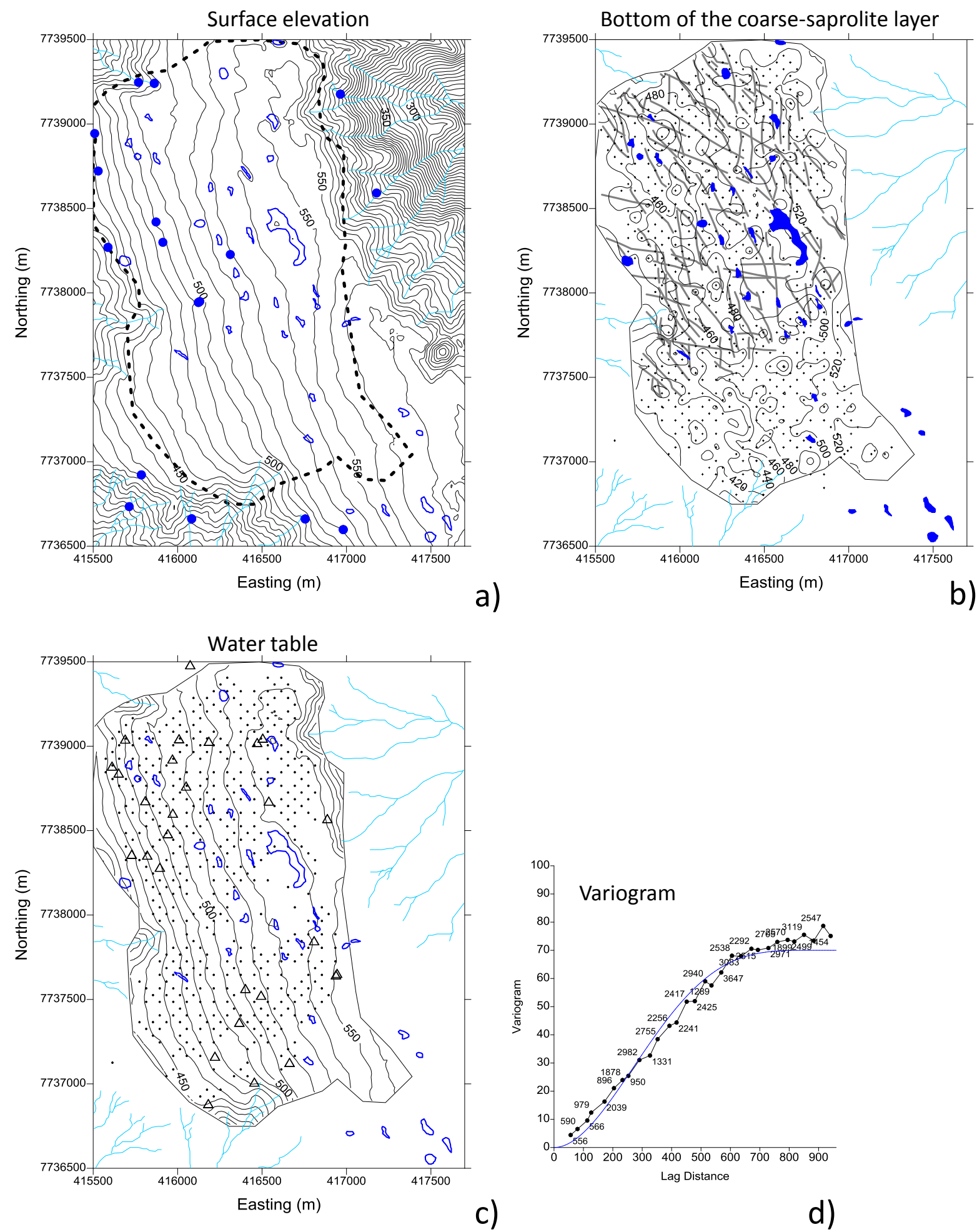

Figure 3 Tiébaghi Massif. a) Curves: Digital Elevation Model (20x20 m cells); Blue circles: springs; Blue shapes: sinkholes. b) Curves: elevation of the bottom of the coarse-saprolite layer; Gray lines: faults; Crosses: exploration boreholes $(n=600)$. c) Curves: elevation of water table in May 2007; Crosses: location of hydraulic head data $(n=475)$; Triangles: location of hydraulic tests $(\mathrm{n}=28)$; d) Variogram model used for establishing Fig. 3c (cubic model, sill: 70, length: $1200 \mathrm{~m}$; anisotropy ratio: 1.4 , dir.: $\mathrm{N} 140^{\circ}$ ); number near data points represents data pairs measurements. 
Published in Journal of Hydrology 550 (2017) 118-129; http://dx.doi.org/10.1016/j.jhydrol.2017.03.075

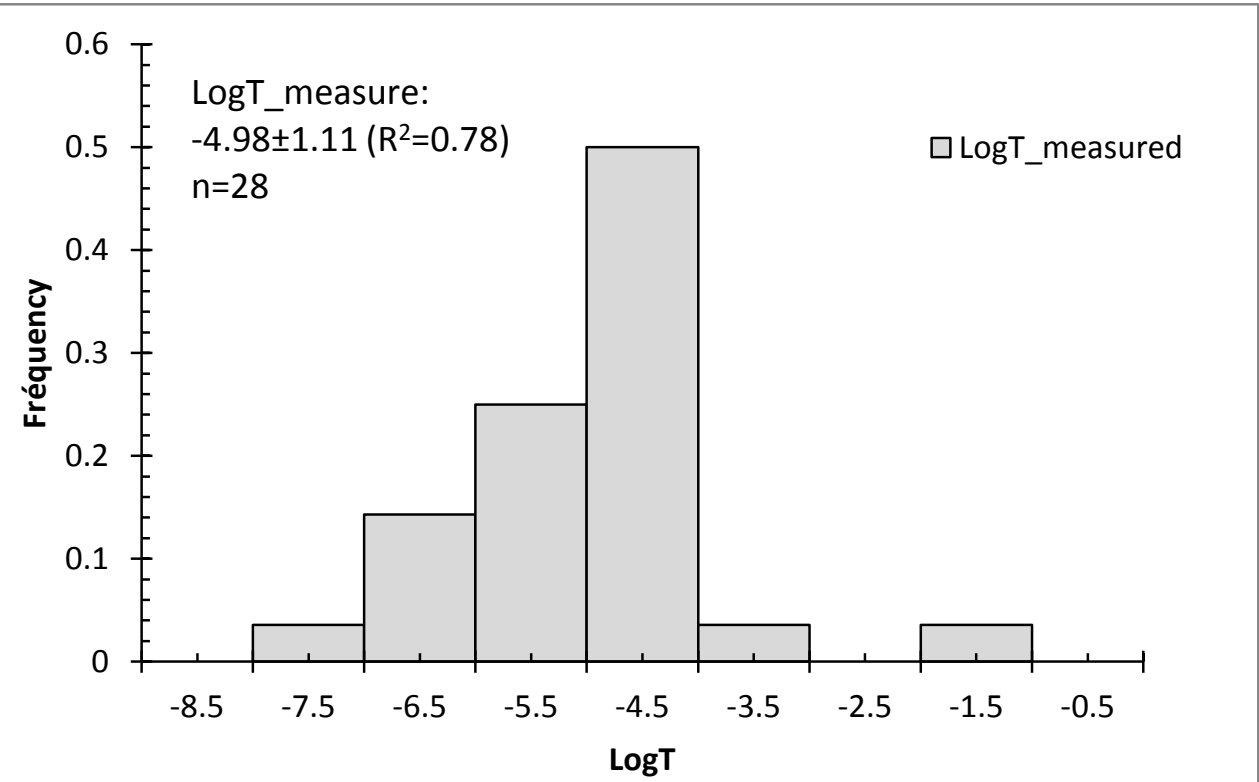

616 Figure 4 Distribution on a logarithmic scale of transmissivity data $(n=28)$. R: linear 617 regression coefficient, \pm : standard deviation. 


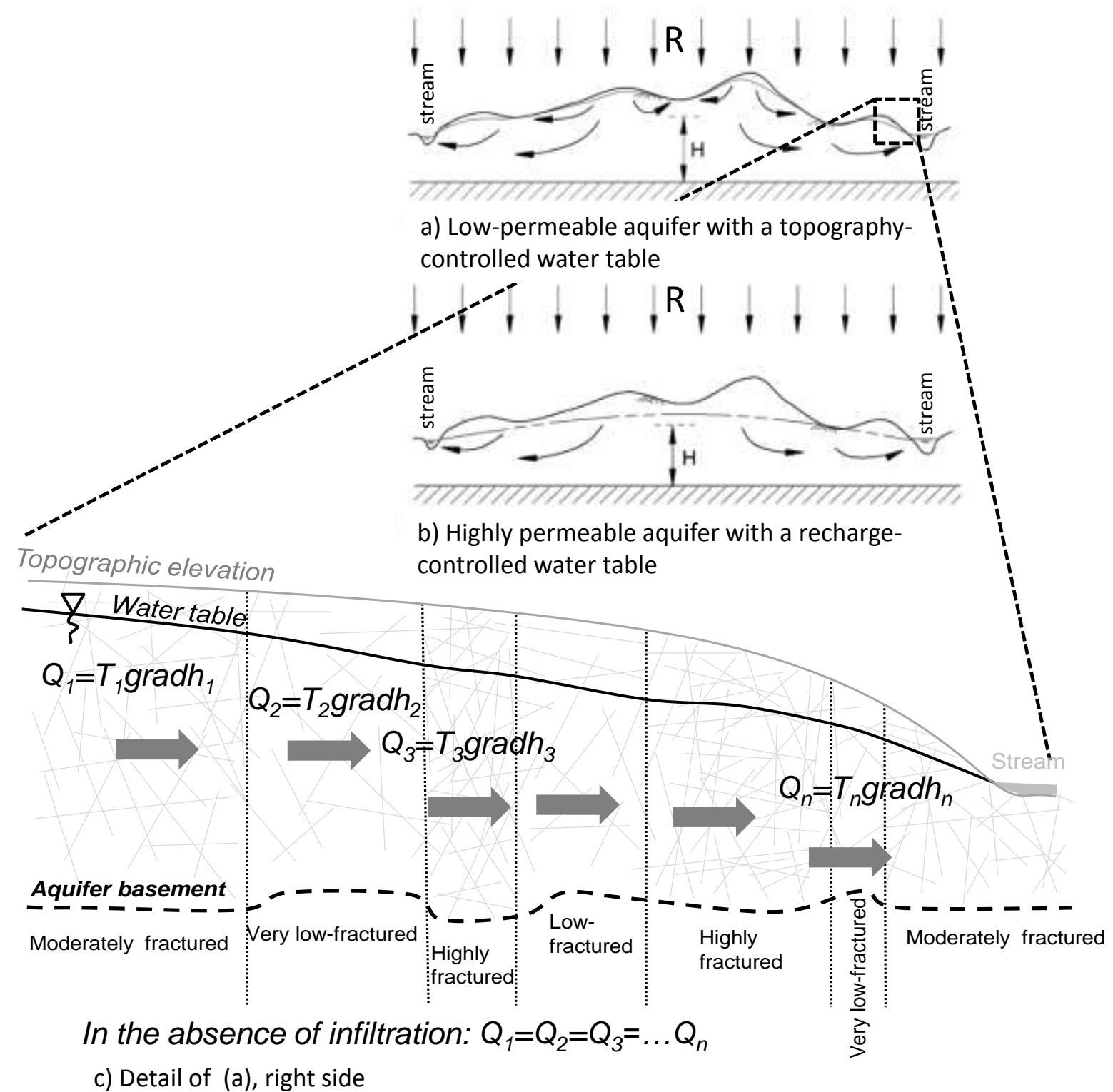

c) Detail of (a), right side

Figure 5 Sketches showing the water table controlled by: a) Topography (low-permeable aquifers), and b) Recharge (highly permeable aquifers); modified from Haitjema and Mitchell-Bruker (2005). c) Detail on topography controlled water-table with expected importance of the topographic slope and of the aquifer transmissivity on the hydraulic gradient. Q: horizontal groundwater flow; $\mathrm{T}_{1}, \mathrm{~T}_{2}, . ., \mathrm{T}_{\mathrm{n}}$ : horizontal aquifer transmissivity and $\operatorname{gradh}_{1}, \operatorname{gradh}_{2}, \ldots, \operatorname{gradh}_{\mathrm{n}}$ : hydraulic head gradient. 


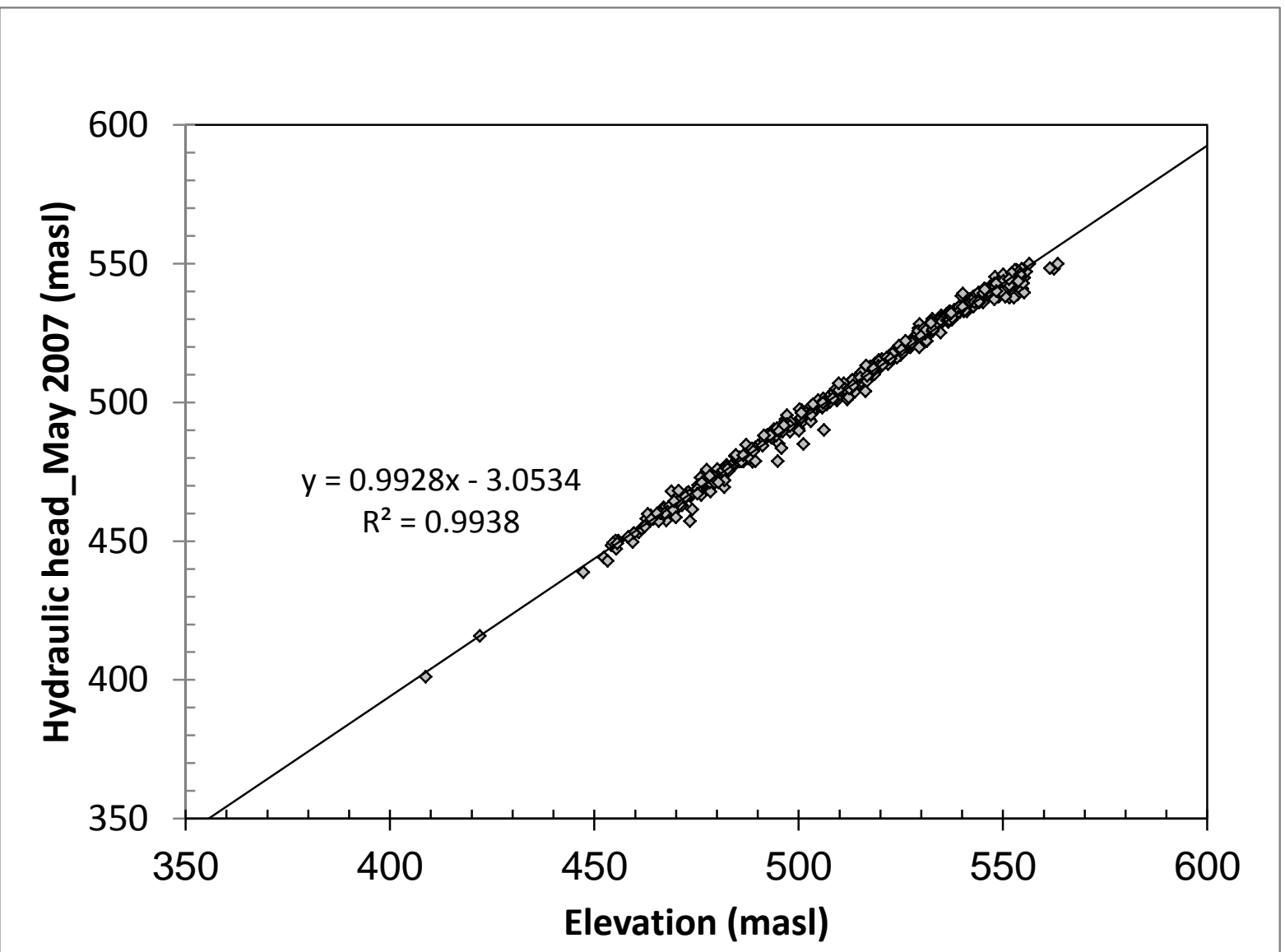

Figure 6 Plot of hydraulic head measurements (May 2007) vs. elevation (in metres above sea level; masl), $n=475$. R: linear regression coefficient. 


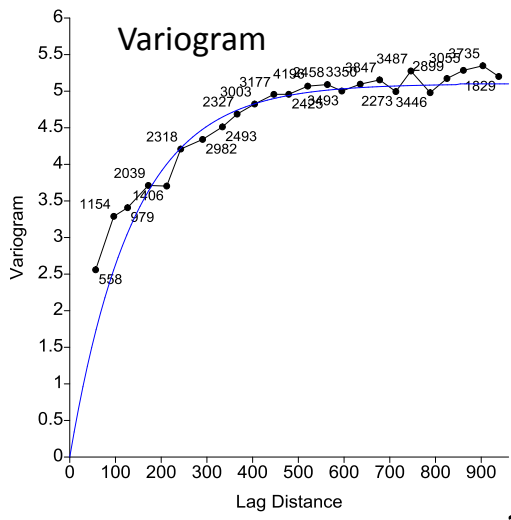

a)

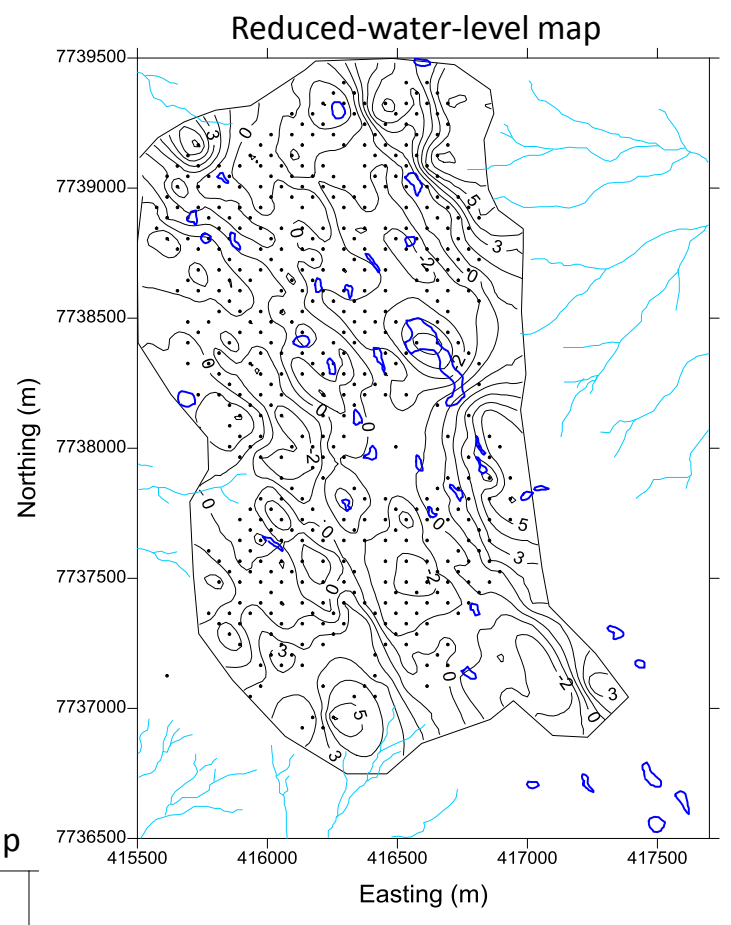

b)

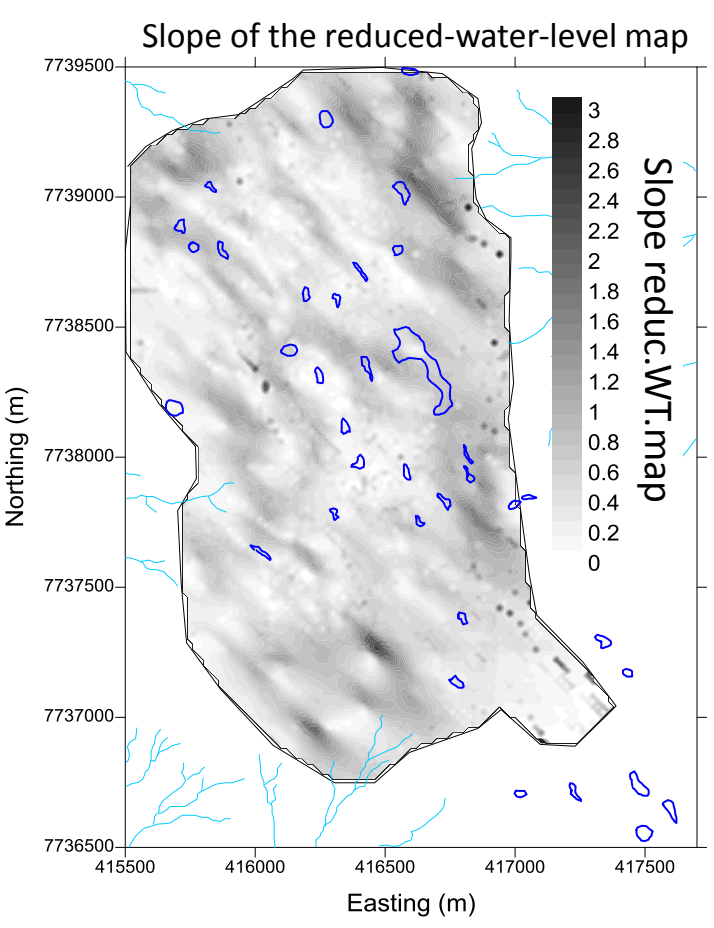

Histogram and log-normal distribution of 1/slope data (logarithmic scale)

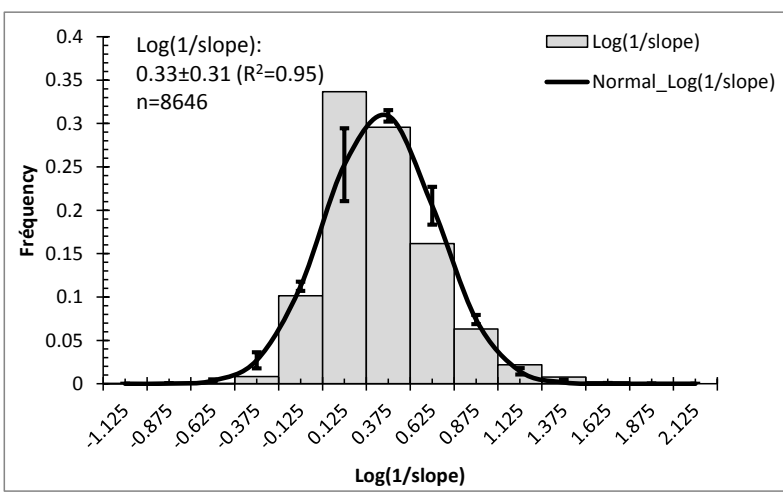

c)

d)

Figure 7 Hydraulic-head data reduced from topographic influence (reduced-water level). a) Variogram model used for establishing Fig. 7b (exponential model, sill: 5.1, length: $190 \mathrm{~m}$; anisotropy ratio: 1.8, dir.: $\mathrm{N} 140^{\circ}$ ); number near data points represents data pairs measurements. b) Reduced-water-level map over 20x20 m cells; dots: hydraulic head data. c) Slope map established from Fig. 7b. d) Histogram and log-normal distribution on a logarithmic scale of $1 /$ slope data $(n=8646)$. $R$ : linear regression coefficient, \pm : standard deviation. 


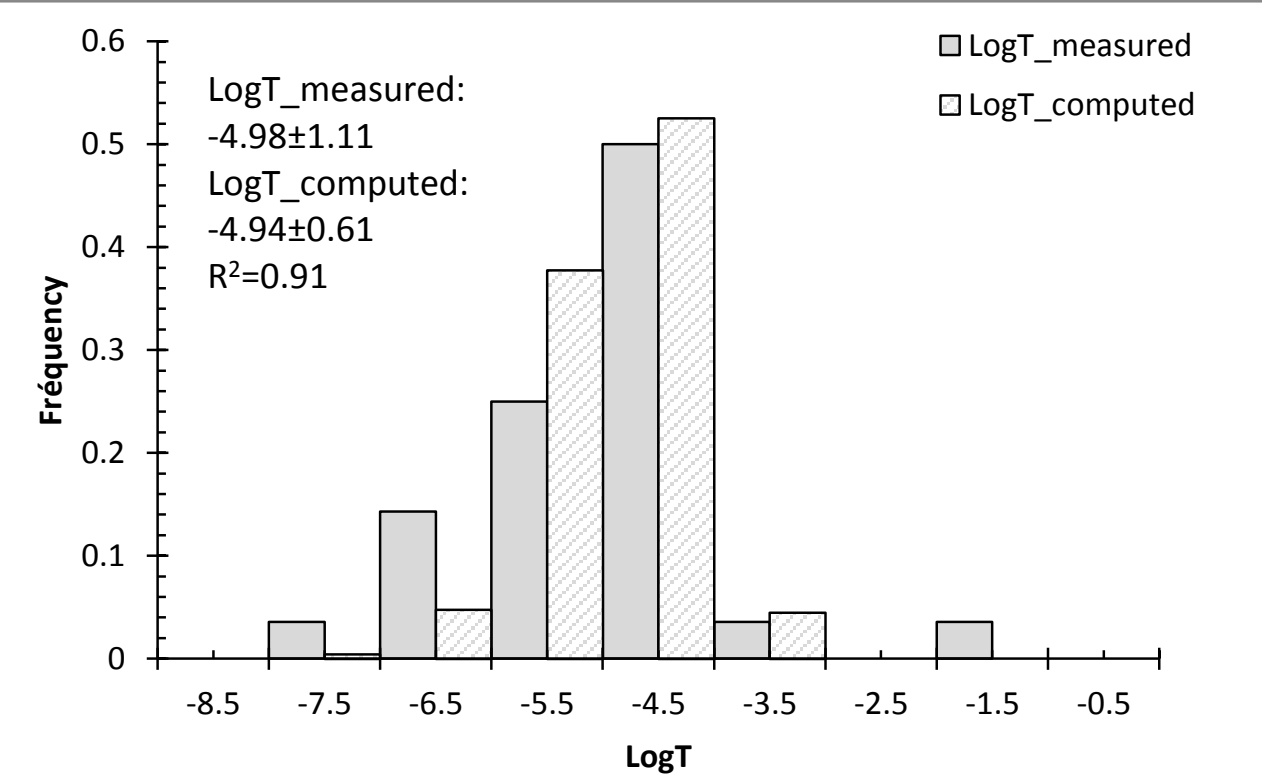

Figure 8 Comparison of the distribution on a logarithmic scale of the transmissivity data modelled with 1/slope data, with those from hydraulic tests. R: linear regression coefficient between the two distributions, \pm : standard deviation. 

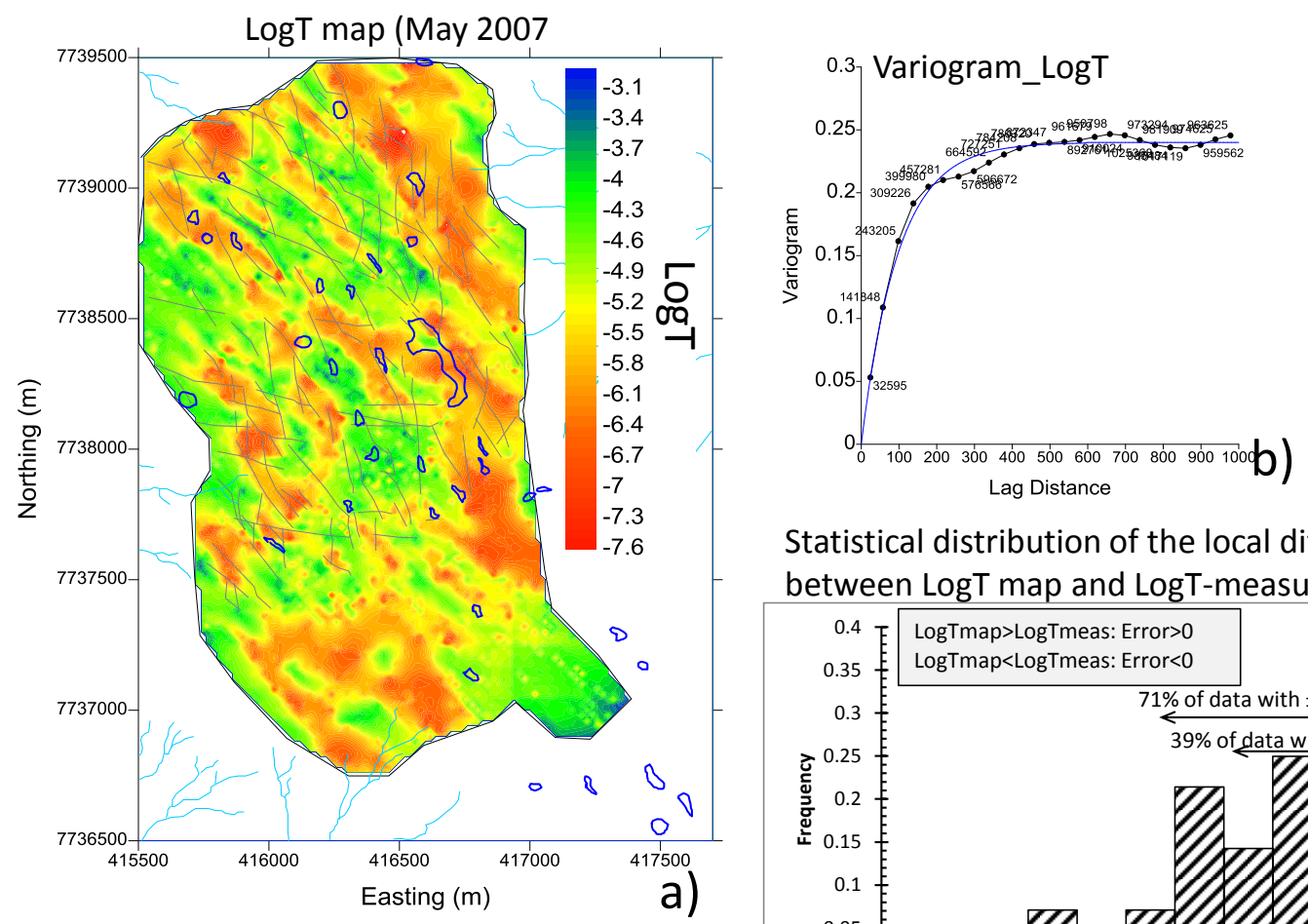

Statistical distribution of the local differences between LogT map and LogT-measured
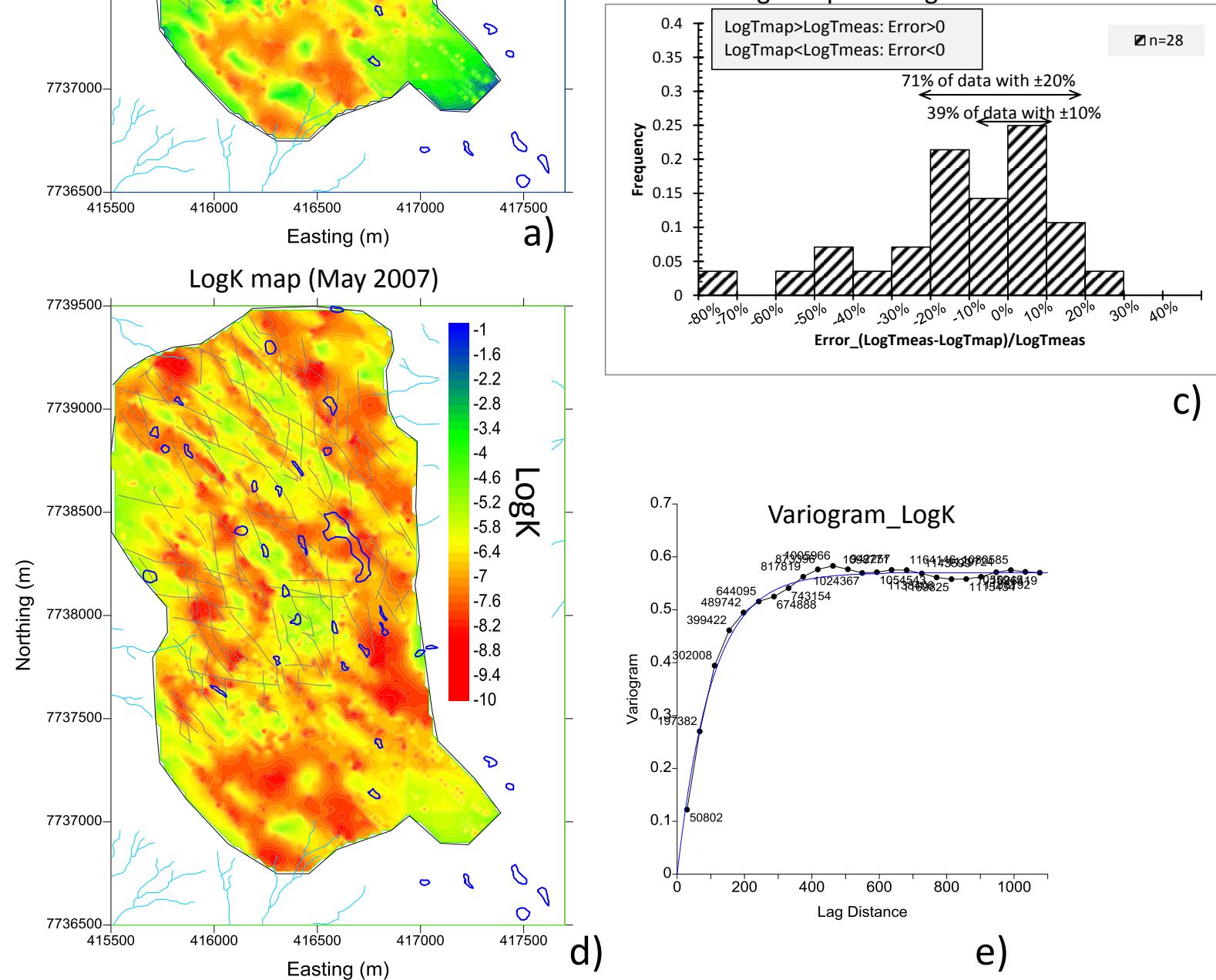

c)

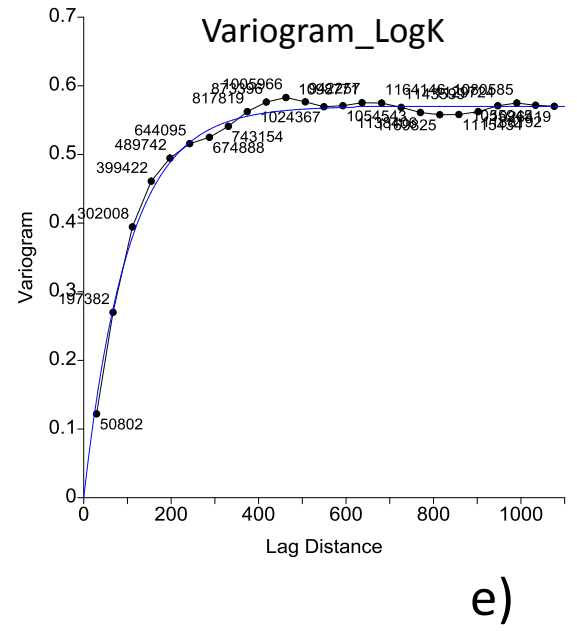

Figure 9 a) Transmissivity map based on 1/slope data, LogT (20x20 m cells). b) Variogram model of LogT (exponential model, sill: 0.24, length: $115 \mathrm{~m}$; anisotropy ratio: 1.4, dir.: $\mathrm{N} 140^{\circ}$ ). c) Statistical distribution of the local differences between LogT based on 1/slope data and LogT measured from hydraulic tests. d) Hydraulic conductivity map LogK (20x20 m cells) established from LogT map, Fig. 3b and Fig. 3c. e) Variogram model of LogK data (exponential model, sill: 0.57, length: $120 \mathrm{~m}$; anisotropy ratio: 1.4 , dir.: $\mathrm{N} 140^{\circ}$ ). On variograms, number near data points represents data pairs measurements. 

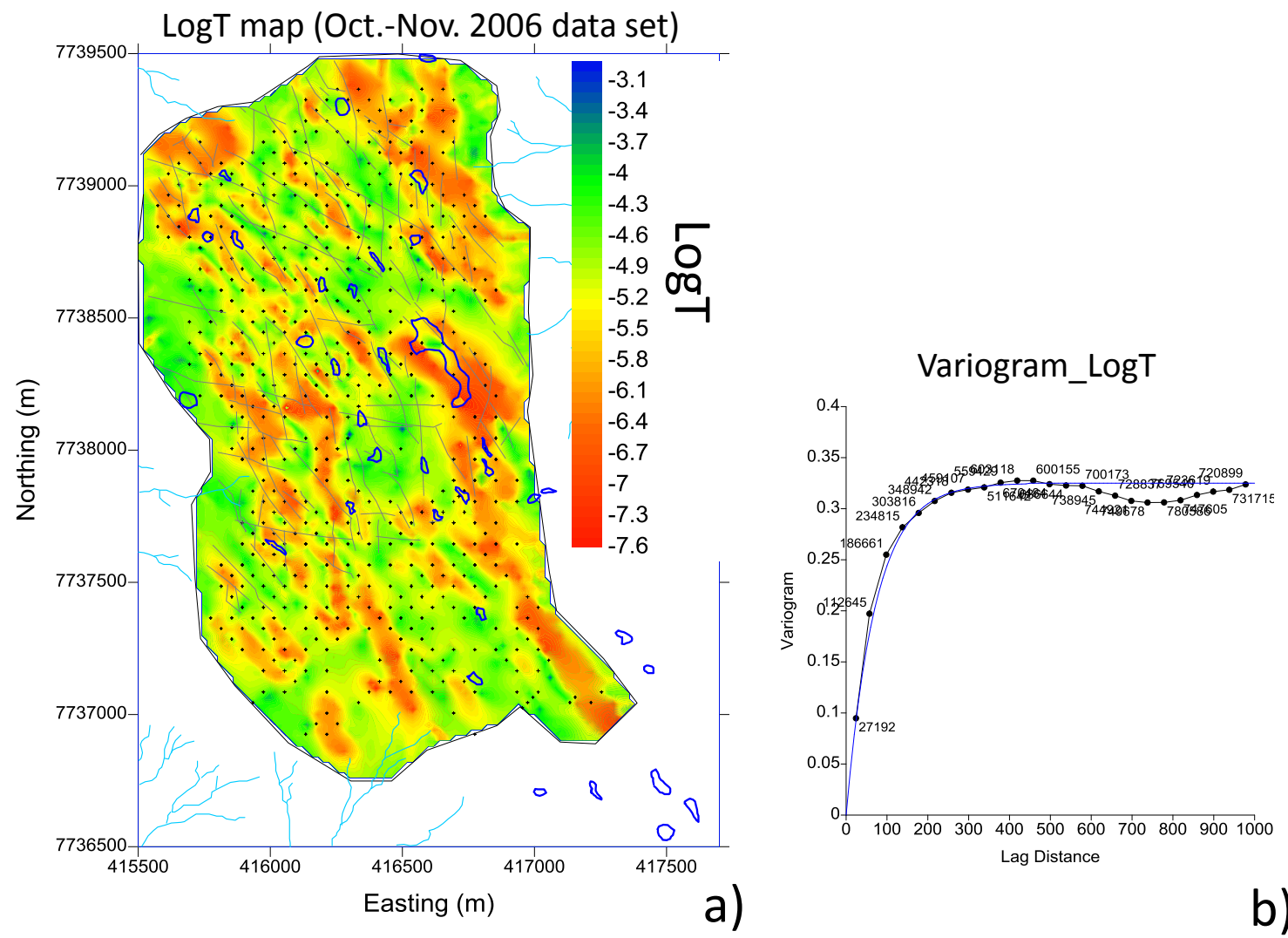

Figure 10 a) Transmissivity map based on Oct.-Nov. 2006 hydraulic-head data ( $\mathrm{n}=543$ ), LogT (20x20 m cells). b) Variogram model of LogT (exponential model, sill: 0.32, length: 85 $\mathrm{m}$; anisotropy ratio: 1.4 , dir.: $\mathrm{N} 140^{\circ}$ ); number near data points represents data pairs measurements. 

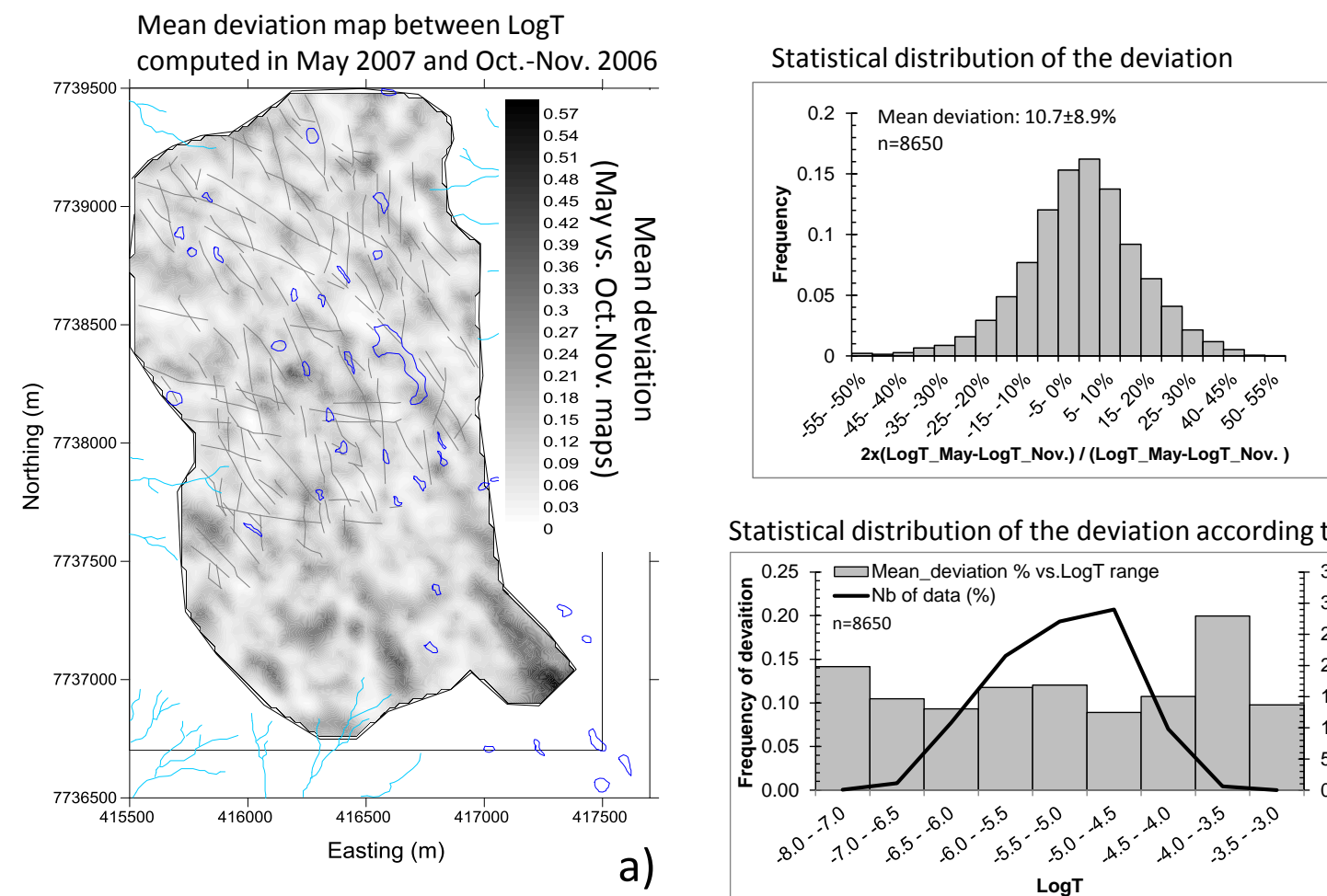

b)

Statistical distribution of the deviation according to LogT

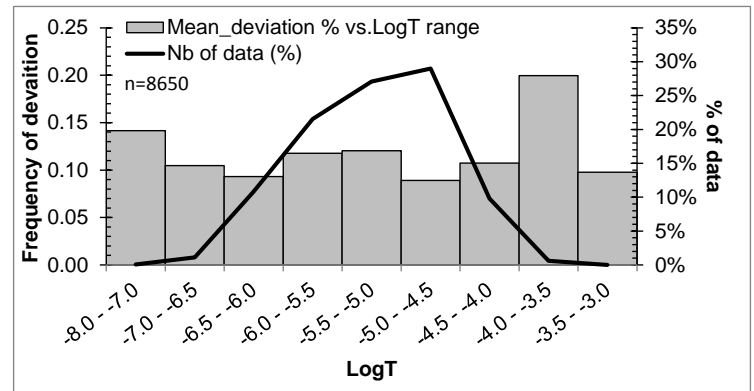

c)

654 Figure 11 Mean deviation between LogT maps computed in May 2007 and Oct.-Nov. 2006.

a) Map. b) Statistical distribution. c) The same as b), but according to LogT ranges. 